Original Research Paper

\title{
Keberadaan Hewan Pengotor Teritip di Infrastruktur Teluk Kunyit, Pantai Sariringgung dan Pantai Mutun, Lampung
}

\author{
Hendry Wijayanti ${ }^{1}$, Dhani Gathot Herbowo², Andy Darmawan ${ }^{3}$ \\ ${ }_{1,3}$ Program Studi Biologi, Jurusan Sains, Institut Teknologi Sumatera, Lampung Selatan; \\ ${ }^{2}$ Program Studi Teknik Geologi, Jurusan Teknologi Produksi dan Industri, Institut Teknologi Sumatera, Lampung Selatan;
}

\section{Riwayat artikel}

Received : 12 Desember 2019

Revised : 31 Januari 2020

Accepted : 3 Februari 2020

Published : 7 Februari 2020

*Corresponding Author:

Hendry Wijayanti,

Program Studi Biologi, Jurusan Sains, Institut Teknologi

Sumatera, Jalan Terusan

Ryachudu Way Hui Jati Agung

Lampung Selatan;

Email:

hendry.wijayanti@bi.itera.ac.id

\begin{abstract}
Abstrak: Teritip merupakan salah satu hewan pengotor yang umum hidup menempel pada infrastruktur buatan manusia yang teredam di dalam perairan laut. Fenomena penempelan teritip mengakibatkan kerusakan struktur bangunan pada infrastruktur di perairan laut. Tujuan penelitian ini menginventarisasi keberadaan jenis teritip yang menempel pada infrastruktur yang ada di area pantai yang berada di Teluk kunyit, Pantai Sariringgung dan Pantai Mutun sebagai langkah awal dalam pengendalian hewan pengotor. Penelitian dilakukan dengan metode survei selama bulan April and November 2018. Pada kedua Pantai Sariringgung dan Pantai Mutun ditemukan dua spesies teritip, Amphibalanus amphitrite dan Microeuraphia withersii. Namun, jenis teritip yang ditemukan di Teluk Kunyit hanya satu spesies Cthtamalus malayensis..
\end{abstract}

Kata kunci: introduksi, biofouling, zona intertidal, Teluk Lampung.

Abstract: Barnacle is the most common biofouling in the manmade submerged structures. Barnacles are a serious problem which leading the detriment of coastal structures. The aim of the study was to investigate the dataset of barnacale communities in Lampung shores, in order to monitor developing of biofouling. Three coastal areas of Teluk Kunyit, Sariringgung and Mutun were investigated between April and November 2018. It was found that two species, Amphibalanus amphitrite and Microeuraphia withersii, are found in both costal areas. In contrast, only colonial species of Cthtamalus malayensis has been found abundance in Teluk kunyit area.

Keywords: introduction, biofouling, intertidal zone, Lampung Bay

\section{Pendahuluan}

Teritip merupakan salah satu hewan biofouling yang umum menempel pada struktur buatan manusia yang terendam di dalam perairan.laut. fenomena penempelan teritip berakibat pada kerapuhan struktur material penopang (Demirel et al., 2017). Salah satu kejadian biofouling terjadi di perairan Jepang, spesies teritip Megabalanus coccopoma, yang habitat aslinya berasal dari Panama Brazil, merusak tiang pancang dan tali budidaya tiram dan menjadi hama budidaya tiram (Yamaguchi et al., 2009). Larva teritip memungkinkan terbawa secara pasif oleh kapal yang singgah dan buangan air ballast.

Keberadaan teritip di dunia internasional sering menjadi pusat perhatian karena akibat yang ditimbulkan karena hewan pengotor ini. Biaya yang dikeluarkan untuk mengatasi hewan pengotor ini cukup besar, sebagai contoh Angkatan Laut Amerika diperkirakan menghabiskan biaya tahunan sebesar hampir 260 juta US dollar untuk pembiayaan cat dan pembersihan (Schultz, 2007).

Perkembangan infrastruktur untuk mendukung perekonomian sedang menjadi fokus utama pemerintah terkait pembangunan infrastruktur berbasis maritim yang tercantum pada Peraturan Presiden Nomor 16 Tahun 2017, salah satunya pembangunan yang berada di kawasan wisata Pantai Sariringgung dan Pantai Mutun. Resiko yang ditimbulkan oleh teritip dan hewan biofouler lainnya dapat menelan biaya dan kerugian yang tidak sedikit. Serta kesulitan yang muncul dalam proses perbaikan (Wolff, 2005). Keberadaan teritip di ekosistem, selain 
menyebabkan kerugian, juga penting sebagai rantai makanan dan tempat hidup bagi hewan-hewan yang hidup di daerah pantai (Wares and Thurman, 1991).

Permasalahan yang melatarbelakangi penelitian ini adalah konservasi lingkungan berkaitan dengan keberadaan dan keragaman spesies teritip yang menempel pada infrastruktur maritim di perairan Teluk Lampung serta untuk mendata spesies yang bersifat biofouling terhadap infrastruktur yang ada.

\section{Bahan dan Metode}

\section{Pengambilan dan Identifikasi Sampel Teritip}

Penelitian ini dilaksanakan di perairan Teluk Kunyit $\quad\left(5^{\circ} 31^{\prime \prime} 48.48^{\prime} \mathrm{S} \quad 105^{\circ} 21^{\prime \prime} 16.15^{\prime} \mathrm{E}\right), \quad$ Pantai Sariringgung (5'30"48.46'S 105'15"41.83'E) dan Pantai Mutun (5'33'27.43'S 195'15"9.37'E), Lampung. Lokasi pengambilan sampel difokuskan di sepanjang lokasi yang yang terdapat infrastruktur buatan manusia (kapal, pelabuhan, pipa, tiang besi, tiang kayu, dan batu) yang tertempeli teritip sebagai sampel utama penelitian ini. Pengambilan sampel dilaksanakan dalam 8 bulan, dari bulan April-November 2018.

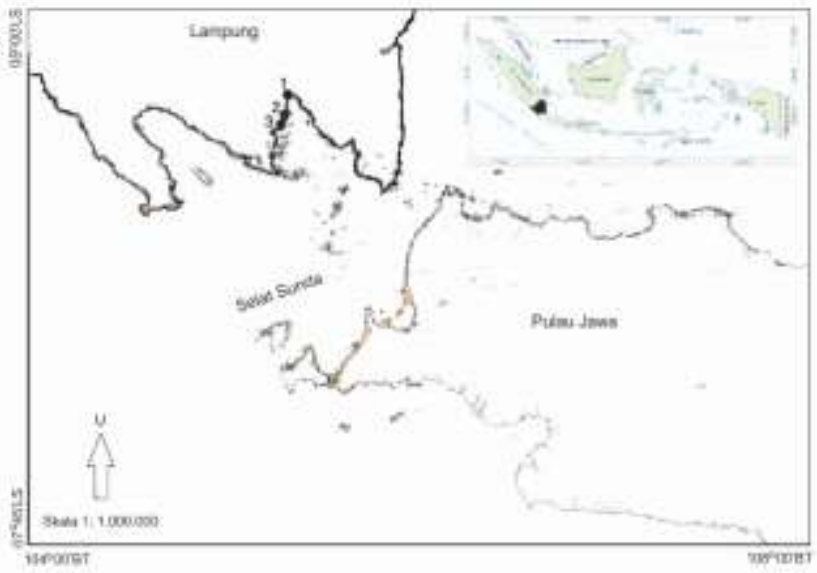

Gambar. 1. Lokasi Sampling: Teluk Kunyit (1); Pantai Mutun (2); Pantai Sariringgung (3).

Penelitian ini dilakukan menggunakan metode survei, setiap lokasi penelitian yang terdapat bangunan infrastruktur dilakukan pengecekan spesies teritip yang mungkin menempel dan dilakukan pencatatan spesies yang ditemukan dan pendeskripsian tipe substrat penempelan. Teritip yang ditemukan difiksasi dan disimpan menggunakan ethanol $95 \%$ untuk penyimpanan kurun waktu jangka panjang dan keperluan analisis lanjutan (misal: berdasarkan sekuens DNA yang masih akan dilakukan kedepan) (Houde and Braun, 1988; Carter, 2004; Chakraborty et al., 2006).

Sampel teritip, selanjutnya, diidentifikasi berdasarkan pada deskripsi karakteristik morfologi teritip pada bagian keras berupa cangkang (parietas) dan plat penutup cangkang (opercular plat). Identifikasi spesies teritip menggunakan buku identifikasi Darwin, 1851 \& 1954; Chan, 2006; Hagner \& Vezo, 2006; Chan et al., 2009; Yamaguchi et al., 2009; Shahdadi \& Sari 2010; Wijayanti et al., 2010; Prabowo et al., 2011; Reis et al., 2011; Tsang et al., 2012; Shahdadi et al., 2014.

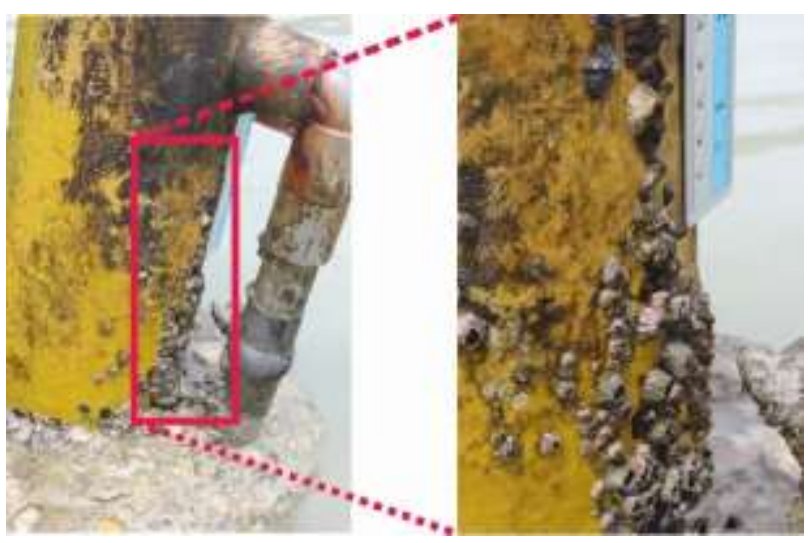

Gambar. 2. Penempelan Teritip pada Tiang Besi di Pantai Sariringgung

\section{Hasil dan Pembahasan}

\section{Keragaman Teritip}

Data teritip dewasa yang diperoleh dari infrastruktur yang terdapat di ketiga lokasi yang berada di Teluk Lampung menunjukkan sangat rendahnya biodiversitas teritip, terdiri dari Familia Balanidae (Amphibalanus amphitrite) dan Chthamalidae (Chthamalus malayensis dan Microeuraphia withersii) (Gambar 3). Teritip jenis $C$. malayensis hanya ditemukan di lokasi Teluk Kunyit, sedangkan $M$. withersii dan $A$. amphitrite ditemukan di Pantai Mutun dan Pantai Sariringgung.

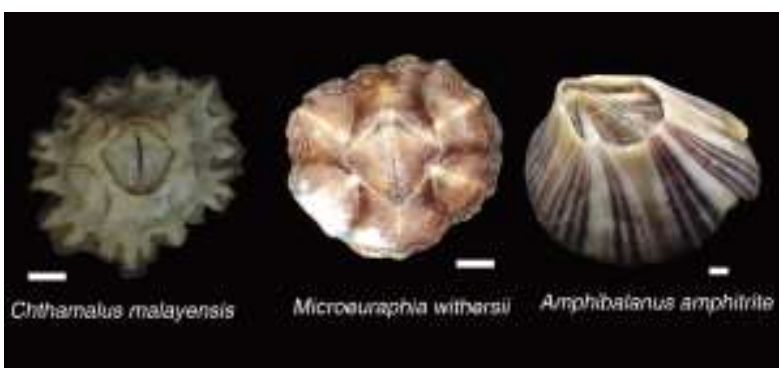

Gambar. 3. Tiga spesies yang tercatat ditemukan di Teluk Kunyit, Pantai Mutun dan Pantai Sariringgung. Bar $=1 \mathrm{~mm}$ 
Teritip yang ditemukan di daerah Teluk Kunyit merupakan jenis teritip $C$. malayensis yang umumnya menempati daerah tertinggi pada mid upper shores pada substrat keras dan toleran terhadap sinar matahari kuat dengan suhu mencapai $45^{\circ}$ (Wethey, 2002) serta tersebar luas di Samudera Hindia, perairan Indo-Malayan dan pantai-pantai tropis Australia (Southward dan Newman, 2003). Daerah sekitar Teluk Kunyit merupakan daerah bebatuan penahan ombak (gambar 4), yang langsung terpapar oleh panas matahari, sehingga memungkinkan genus Chthamalus dominan dijumpai pada daerah tersebut.

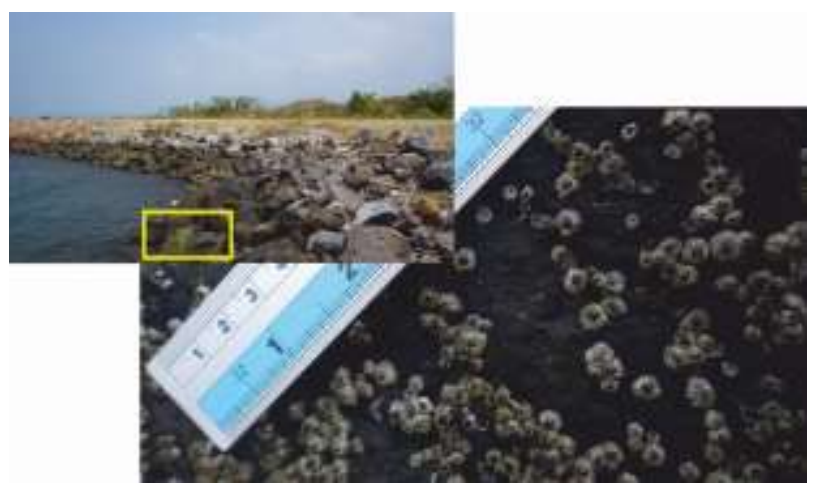

Gambar. 4. Penempelan Teritip pada batu penahan ombak di Teluk Kunyit

Teritip yang ditemukan Teritip jenis $M$. withersii yang ditemukan di Pantai Mutun menempel banyak hanya pada bekas ponton dock yang telah lama tidak digunakan dan keberadaannya berkompetisi dengan A. amphitrite (gambar 5). Namun, pada akhir bulan November 2018, ponton dock tersebut dibersihkan dari area Pantai Mutun. A. amphitrite ditemukan melimpah dan menempel di tiang beton dan semen yang ada di pantai.

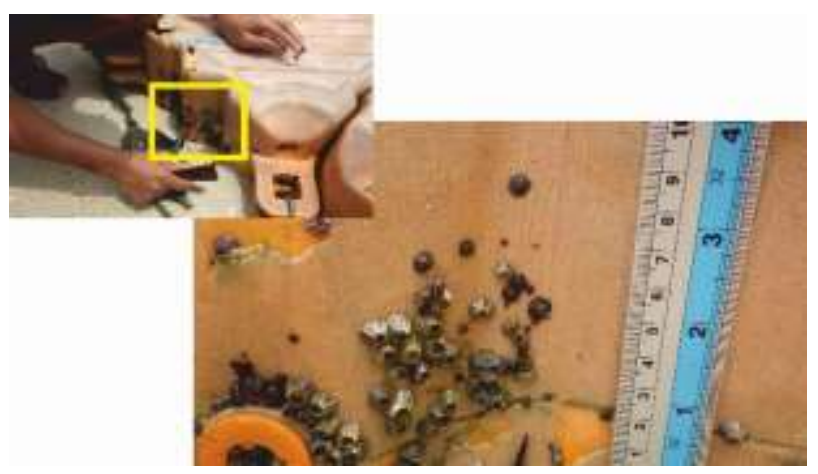

Gambar. 5. Penempelan Teritip pada bekas ponton dock di Pantai Mutun

Penelitian serupa telah dilakukan oleh Wijayanti et al., 2010 di sekitar Pelabuhan Bakauheni dan mendokumentasikan jenis-jenis teritip yang menempati area tersebut. Salah satu teritip yang ditemukan adalah teritip A. amphitrite. Teritip A. amphitrite merupakan spesies kosmopolit yang berasal dari kelompok Balanomorpha, yang tersebar luas tidak hanya di daerah Indo-West Pacific tetapi juga di seluruh dunia (gambar 6) (Prabowo and Yamaguchi, 2005). Secara umum, teritip dikenal dari bentuk A. amphitrite, sehingga jenis ini dijuluki type species (Prabowo and Adli, 2010).

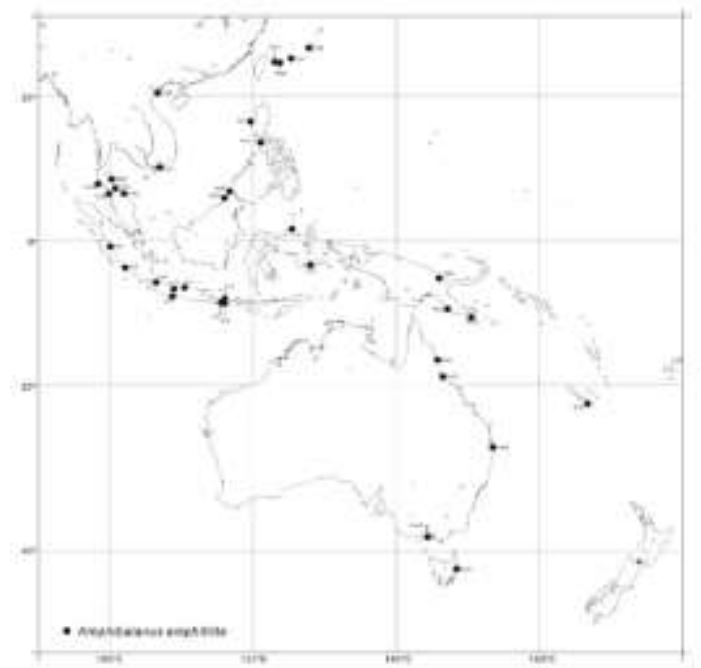

Gambar 6. Peta zoogeografis Amphibalanus amphithrite yang ditemukan di Indo-West Pacific (Persebaran A. amphithrite di wilayah Lampung belum belum terdokumentasi) (Prabowo, 2010)

Selain itu, pada penelitian ini ditemukan teritip jenis $M$. withersii yang sebelumnya tidak ditemukan pada saat Wijayanti dan tim melakukan pendataan. Jenis teritip M. withersii tercatat ditemukan pada daerah pasang tertinggi dan lebih terlindung dari cahaya matahari langsung di tiang-tiang pelabuhan di Pelabuhan Mentawai (Sulistiono, 2010).

Kemiripan jenis teritip yang ditemukan di Pantai Sariringgung dan Pantai Mutun dimungkinkan disebabkan oleh kedekatan letak geografis kedua pantai tersebut dan kecenderungan kondisi fisika kimia perairan kedua pantai cenderung memiliki kesamaan salinitas berkisar sekitar 33 ppt dan temperatur air berkisar 26$27^{\circ} \mathrm{C}$. Selain itu, kapal-kapal nelayan dan wisata melakukan perjalanan melintasi kedua pantai sehingga secara tidak langsung membawa larva-larva teritip.

Setiap lokasi sampling pantai memiliki keadaan lingkungan dan jenis substrat yang berbeda, sehingga teritip yang ditemukan juga berbeda. Jenis substrat menentukan keberhasilan penempelan teritip dan mempengaruhi komposisi teritip yang mampu bertahan hidup dan berkembangbiak (Southward \& Crisp, 1956; Hutomo et al., 1977) serta reaksi terhadap perubahan dan perbedaan kondisi hidrologis suatu perairan 
(Kuriandewa, 1995). Selain itu, kondisi larva juga ikut andil dalam penentuan penempelan habitat (Miron et al., 2000), sehingga hanya larva yang mampu bertahan dari tekanan lingkungan yang mampu berkembang sampai dewasa.

\section{Kesimpulan}

Jenis hewan pengotor teritip yang ditemukan di ketiga area tergolong dalam 2 familia dan 3 spesies yaitu familia Chthamalidae terdiri atas Chthamalus malayensis dan Microeuraphia withersii dan familia Balanidae terdiri atas Amphibalanus amphitrite. Berdasarkan kondisi habitatnya, Chthamalus malayensis mampu bertahan pada kondisi lingkungan berombak, sedangkan Chthamalus malayensis dan Microeuraphia withersii menempati zona intertidal berombak tenang.

\section{Ucapan Terima kasih}

Ucapan terima kasih penulis sampaikan kepada semua pihak yang telah membantu dalam proses penelitian ini dan hibah penelitian Mandiri ITERA dengan nomor kontrak No: 236/IT9.A/SK/PP/2018 atas dukungan dana bagi penelitian ini.

\section{Daftar Pustaka}

Chakraborty, A., M. Sakai \& Y. Iwatsuki (2006). Museum fish specimens and molecular taxonomy: a comparative study on DNA extraction and preservation techniques. Journal of Applied Ichthyology 22(2):160-166. https://doi.org/10.1111/j.1439-0426.2006.00718.x

Chan BKK, Prabowo RE \& Lee K-S. (2009). Crustacean Fauna of Taiwan: Barnacles, Volume I Cirripedia: Thoracica Excluding the Pyrgomatidae and Acastinae. National Taiwan Ocean University.

Chan, BKK. (2006). Ecology and Biodiversity of Rocky Intertidal Barnacles Along a Latitudinal Gradient; Japan, Taiwan and Hong Kong. Publ. Seto Mar. Biol. Lab. (Spec. Publ. Ser.). 8(1-10). https://www.researchgate.net/publication/321735 $\underline{86}$

Darwin, C. (1851). A Monograph on the Sub-Class Cirripedia, with Figures of All the Species. Ray Society Publications: Ray Society. https://doi.org/10.5962/bhl.title.2104

Darwin, C. (1854). A Monograph on the Subclass Cirripedia with Figures of All Species. London, Ray Society. https://doi.org/10.5962/bhl.title.2104
Fernandes, J.N., Cruz, T. \& Syoc, R.V. (2010). Pollicipes caboverdensis sp. nov. (Crustacea: Cirripedia: Scalpelliformes), an Intertidal Barnacle from the Cape Verde Islands. Zootaxa. 2557: 29-38. https://doi.org/10.5281/zenodo.196929

Hagner, C. \& Vezo, T. (2006). Guide to ducks and geese. Mechanicsburg, PA: Stackpole Books.

Hammer, Ø., Harper, D.A.T. \& Ryan P.D. (2001). Past: Paleontological Statistics Software Package for Education and Data Analysis. Palaeontol Electron. $\quad 4(1)$ : 9 https://www.researchgate.net/publication/259640 $\underline{226}$

Hutomo, M., Arinardi, O.H., Moosa, M.K. \& Romimohtarto, K. (1977). Pengamatan biologis di perairan Muara Karang dengan catatan tentang perikanan di daerah tersebut. Proyek Penelitian Potensi Sumber Daya Ekonomi Lembaga Oseanologi Nasional LIPI, Jakarta.

Kuriandewa, T.E. (1995). Pengaruh orientasi substrat, kedalaman dan lokasi perairan terhadap pola distribusi biota pengotor. Seminar Ilmiah Nasional dalam rangka peringatan lustrum VII Fakultas Biologi UGM, Yogyakarta.

Macho, G., Vázquez, E., Giráldez, R. \& Molares, J. (2010). Spatial and temporal distribution of barnacle larvae in the partially mixed estuary of the Ría de Arousa (Spain). J Exp Mar Biol Ecol. 392(1-2): 129-139. https://doi.org/10.1016/j.jembe.2010.04.017.

Miron, G.L.J., Walters, R., Tremblay \& Bourget, E. (2000). Physiological condition and barnacle larval behavior: A preliminary look at the relationship between TAGI DNA ratio and larval substratum exploration in Balanus amphitrite.

Marine

Ecology Progress Series, 198: 303-

310. https://doi.org/10.3354/meps198303

Prabowo, R.E. (2005). A new mangrove barnacle of the Balanus amphitrite complex from Sumbawa Island, Indonesia. Journal of Marine Biological Association of UK. 85: 929-936. https://doi.org/10.1017/S0025315405011902

Prabowo, R.E. (2010). Introduksi Spesies Teritip Asing, Striatobalanus taiwanensis, dari Perairan Taiwan ke Pelabuhan Teluk Bayur Padang. Biodiversitas 
dan Bioteknologi Sumberdaya Akuatik; 2010 Purwokerto Purwokerto: Fakultas Biologi Universitas Jenderal Soedirman.

Prabowo, R.E., Ardli, E.R., Sulistiono \& Wijayanti, H. (2011). Biodiversitas Teritip Intertidal (Cirripedia: Balanomorpha) di Pantai-Pantai Propinsi Lampung, Bengkulu, dan Sumatra Barat. Kongres dan Seminar Masyarakat Taksonomi Kelautan Indonesia I. Pusat Penelitian Oseanografi-LIPI. 208-218.

Pranowo, W.S., Kuswardhani, A.R.T.D., Kepel, T.L., Kadarwati, U.R., Makarim, S. \& Husrin, S. (2005). Menguak Arus Lintas Indonesia. A Supangat, IS Brodjonegoro, AG Ilahude, I Jaya, dan TR Adi. Jakarta, Pusat Riset Wilayah Laut \& Sumberdaya Non-Hayati, Badan Riset Kelautan dan Perikanan, Departemen Kelautan dan Perikanan.

Shahdadi, A., Sari, A. \& Naderloo, R. (2014). A checklist of the barnacles (Crustacea: Cirripedia: Thoracica) of the Persian Gulf and Gulf of Oman with nine new records. Zootaxa. 3784(3): 201-223. https://doi.org/10.11646/zootaxa.3784.3.1.

Southward, A. J. \& Crisp, D.J. 1956. Fluctuations in the distribution and abundance of intertidal barnacle. Journal of the Marine Biological Association of the United Kingdom, 35: 211-229. DOI: https://doi.org/10.1017/S0025315400009073

Southward, A. J. \& Newman, W.A. (2003). A review of some common Indo-Malayan and western Pacific species of Chthamalus barnacles (Crustacea: Cirripedia).

Journal of the Marine Biological Association of the United Kingdom, 83: 797- 812. DOI: https://doi.org/10.1017/S0025315403007835h

Sulistiono. (2010). Struktur Komunitas Teritip Intertidal di Beberapa Pantai Propinsi Sumatera Barat dan Bengkulu (Skripsi). Universitas Jenderal Soedirman: Purwokerto.

Tsang, L.M., Achituv, Y., Chu, K.H. \& Chan, B.K.K. (2012). Zoogeography of Intertidal Communities in the West Indian Ocean as Determined by Ocean Circulation Systems: Patterns from the Tetraclita Barnacles. PLoS ONE. 7(9): e45120. https://doi.org/10.1371/journal.pone.0045120

Webber, H. \& Thurman, H. (1991). Marine Biology. New York: Harper Collins Publishers.
Wethey, D.S. (2002). Biogeography, Competition, and Microclimate: The Barnacle Chthamalus fragilis in New England. Integrative and Comparative Biology, 42:872-880. https://doi.org/10.1093/icb/42.4.872

Wijayanti, H., Prabowo, R.E., \& Ardli, E.R. (2010). Biodiversitas Teritip Intertidal di Pantai Lampung. Proceeding Seminar Nasional Biologi; Purwokerto: Fakultas Biologi Universitas Jenderal Soedirman. 116-121pp.

Wolf, W. J. (2005). Non-indigenous marine and estuariane species in the Netherlands. Zool. Med. 79 (1), 1-116. ISSN 0024-0672

Yamaguchi, T., Prabowo, R.E., Ohshiro, Y., Shimono, T., Jones, D., Kawai, H., Otani, M., Oshino, A., Inagawa, S. ... Akaya, T. (2009). The Introduction to Japan of the Titan Barnacle, Megabalanus coccopoma (Darwin, 1854) (Cirripedia: Balanomorpha) and the Role of Shipping in its Translocation. Biofouling. 25(4): 325-333. https://doi.org/10.1080/08927010902738048. 